\title{
Synaptic Cleft Acidification and Modulation of Short-Term Depression by Exocytosed Protons in Retinal Bipolar Cells
}

\author{
Mary J. Palmer, Court Hull, Jozsef Vigh, and Henrique von Gersdorff \\ The Vollum Institute, Oregon Health and Science University, Portland, Oregon 97239
}

The release of vesicular protons during exocytosis causes a feedback inhibition of $\mathrm{Ca}^{2+}$ channels in photoreceptor terminals; however, the effect of this inhibition on subsequent exocytosis has not been studied. Here we show that a similar L-type $\mathrm{Ca}^{2+}$ channel inhibition occurs in bipolar cell terminals in slices of goldfish retina, and we investigate the effect that this has on subsequent exocytosis with membrane capacitance measurements. We find that transient $\mathrm{Ca}^{2+}$ current inhibition is correlated with exocytosis and modulated by the concentration of extracellular $\mathrm{pH}$ buffer. $\mathrm{Ca}^{2+}$ current inhibition is negligible in acutely dissociated terminals, demonstrating the importance of an intact synaptic cleft. The sensitivity of bipolar cell $\mathrm{Ca}^{2+}$ currents to extracellular $\mathrm{pH}$ was assessed: channel conductance is reduced and activation is shifted to more positive potentials by acidification. The effect of $\mathrm{Ca}^{2+}$ current inhibition on subsequent exocytosis was investigated by measuring paired-pulse depression. Under conditions in which there is a large amount of inhibition of $\mathrm{Ca}^{2+}$ influx, the degree of paired-pulse depression is significantly reduced. Finally, we show that under physiological (bicarbonate) buffering conditions, pronounced $\mathrm{Ca}^{2+}$ current inhibition occurs after exocytosis ( $~ 60 \%$ peak inhibition), which can decrease subsequent exocytosis during single depolarizations. We estimate that exocytosis is accompanied by a transient change in synaptic cleft $\mathrm{pH}$ from 7.5 to $\sim 6.9$. We suggest that this effect serves as an activity-dependent modulator of exocytosis at ribbon-type synapses where a large and compact coterie of vesicles can fuse at each active zone.

Key words: goldfish retina; bipolar cell; presynaptic terminal; $\mathrm{Ca}^{2+}$ current; synaptic ribbon; vesicular pH; paired-pulse depression; exocytosis; membrane capacitance

\section{Introduction}

Synaptic vesicles use an $\mathrm{H}^{+}$-ATPase to produce an electrochemical gradient that drives transport of neurotransmitter into the vesicle (Liu and Edwards, 1997). Consequently, vesicular $\mathrm{pH}$ is low (pH 5.7 in hippocampal neurons) (Miesenböck et al., 1998). Synaptic activity is associated with a transient decrease in extracellular pH in hippocampal slices (Krishtal et al., 1987) and a loss of vesicular acidification (Miesenböck et al., 1998), consistent with release of protons into the synaptic cleft. Photoreceptors contain $\mathrm{Ca}^{2+}$ channels that are known to be sensitive to extracellular $\mathrm{pH}$. Acidification causes a decrease in conductance and shift in activation to more positive potentials (Barnes and Bui, 1991), which has also been observed for L-type $\mathrm{Ca}^{2+}$ channels in other systems (Hess et al., 1986; Iijima et al., 1986). Light-sensitive postsynaptic responses were found to be $\mathrm{pH}$ sensitive, with the likely site of action being photoreceptor $\mathrm{Ca}^{2+}$ channels (Barnes et al., 1993).

Recently, this inhibitory effect of acidification on $\mathrm{Ca}^{2+}$ channels has been shown to be induced by exocytosed protons after

\footnotetext{
Received Aug. 1, 2003; revised 0ct. 21, 2003; accepted 0ct. 21, 2003.

This work was supported by National Institutes of Health/National Eye Institute and Pew Biomedical Research Scholar grants. We thank Drs. Ed McCleskey, Mark Connor, and Craig Jahr for valuable discussions.

Correspondence should be addressed to Dr. H. von Gersdorff, The Vollum Institute, Oregon Health and Science University, 3181 Southwest Sam Jackson Park Road, Portland, OR 97239. E-mail: vongersd@ohsu.edu.

M. J. Palmer's present address: Medical Research Council Centre for Synaptic Plasticity, University of Bristol, BS8 1TD, UK.

Copyright $\odot 2003$ Society for Neuroscience 0270-6474/03/2311332-10\$15.00/0
}

transmitter release in cone photoreceptors (DeVries, 2001); however, this study of $\mathrm{Ca}^{2+}$ current inhibition by vesicular protons did not extend to a detailed investigation of the effect on subsequent exocytosis (Traynelis and Chesler, 2001). The size of the bipolar cell response was only slightly potentiated in two of five recordings when the concentration of extracellular $\mathrm{pH}$ buffer was increased. Here we investigate whether $\mathrm{Ca}^{2+}$ current inhibition by released vesicular protons leads to subsequent inhibition of exocytosis in a different retinal synaptic terminal: that of the bipolar cell. Bipolar cell and photoreceptor terminals are similar in that transmitter release is activated by slowly inactivating L-type $\mathrm{Ca}^{2+}$ channels ( $\alpha 1 \mathrm{~F}$ type) (Morgans, 2001) and involves the fusion of large numbers of vesicles at active zones that possess synaptic ribbons (Parsons and Sterling, 2003). Photoreceptor ribbons, however, are larger and less numerous than the bipolar cell ribbons. We have recently developed a preparation that allows recordings of voltage-clamped membrane currents and capacitance measurements to be made directly from the synaptic terminals of bipolar cells in goldfish retinal slices (Palmer et al., 2003). This provides an ideal system for investigating a reciprocal relationship between $\mathrm{Ca}^{2+}$ influx and exocytosis.

We find that voltage-gated $\mathrm{Ca}^{2+}$ currents in bipolar cell terminals are inhibited in a manner that correlates with exocytosis from the terminal and that the inhibition can be modulated by changing the concentration of extracellular $\mathrm{pH}$ buffer. In addition, $\mathrm{Ca}^{2+}$ currents in dissociated bipolar cell terminals are strongly inhibited by acidification of the extracellular solution. 
These results indicate that the mechanism of $\mathrm{Ca}^{2+}$ current inhibition by released vesicular protons demonstrated by DeVries (2001) in cone photoreceptors also occurs in bipolar cell terminals. Furthermore, we significantly extend previous findings by showing that modulation of $\mathrm{Ca}^{2+}$ current inhibition with extracellular $\mathrm{pH}$ buffer also modulates subsequent exocytosis from the terminal. Finally, we determine the amount of $\mathrm{Ca}^{2+}$ current inhibition and paired-pulse depression that occur under physiological buffering conditions and estimate the change in synaptic cleft $\mathrm{pH}$ that accompanies exocytosis from bipolar cell terminals.

\section{Materials and Methods}

Retinal slice preparation. Retinal slices were prepared from goldfish (Carassius auratus) using standard procedures. In brief, isolated retina was treated for $15 \mathrm{~min}$ with hyaluronidase (1 $\mathrm{mg}$ in $1 \mathrm{ml}$ of medium) to remove vitreous humor, placed ganglion cell layer down on filter paper, and sliced at $250 \mu \mathrm{m}$ intervals using a Narishige slicer (ST-20; Narishige, Tokyo, Japan). Slices were transferred to the recording chamber and perfused continuously $(1 \mathrm{ml} / \mathrm{min}$ ) with medium comprising (in $\mathrm{mm}$ ): $120 \mathrm{NaCl}, 2.5 \mathrm{KCl}, 1.0 \mathrm{MgCl}_{2}, 2.5 \mathrm{CaCl}_{2}, 12$ HEPES, 12 glucose, adjusted to $\mathrm{pH} 7.45$ with $\mathrm{NaOH}, \sim 260 \mathrm{mOsm}$. NaCl was replaced with $\mathrm{Na}$ methane sulfonate for low extracellular $\mathrm{Cl}^{-}$recordings. For experiments requiring high ( $48 \mathrm{~mm}$ ) or low (3 mM) extracellular HEPES, osmolarity was maintained by adjusting the concentration of $\mathrm{NaCl}$. For recordings in bicarbonate buffer, HEPES was replaced with $\mathrm{NaHCO}_{3}(24 \mathrm{~mm}), \mathrm{NaCl}$ was reduced to maintain osmolarity $(108 \mathrm{~mm})$, and the solution was gassed continuously with $95 \% \mathrm{O}_{2} / 5 \% \mathrm{CO}_{2}, \mathrm{pH} 7.5$. For experiments requiring rapid exchange of extracellular solution, the bath perfusion rate was increased to $3 \mathrm{ml} / \mathrm{min}$. Slice preparation and recordings were performed at room temperature, under normal room light conditions.

Identification of bipolar cell terminals. Slices were viewed with broadspectrum white-light DIC optics through a $40 \times$ water-immersion objective and 1.6× zoom tube (Axioskop; Zeiss) and a CCD camera (Hamamatsu, Tokyo, Japan). Bipolar cell terminals were identified by their size, shape, and position in the slice, as well as depolarizationevoked $\mathrm{Ca}^{2+}$ currents and capacitance responses. A subset of terminals were isolated because of severing of the bipolar cell axon during the slicing procedure; this was determined from the capacitative current response to a $-10 \mathrm{mV}$ step from $-60 \mathrm{mV}$ (Palmer et al., 2003, their Fig. $1)$. Terminals fell clearly into two groups. One group was well fit with a double exponential function with a prominent slow component $\left(\tau_{\mathrm{s}}=\right.$ $1.5 \pm 0.1 \mathrm{msec})$ and had low input resistance $(<0.5 \mathrm{G} \Omega)$, and the other group was well fit by either a single fast exponential $\left(\tau_{\mathrm{f}}=98 \pm 5 \mu \mathrm{sec}\right)$ or a double with only a minor slow component and had high input resistance $(>1 G \Omega)$. The first group was classified as intact cells and the second as isolated terminals. This classification was confirmed using Lucifer yellow to image recorded terminals. Intact cells and isolated terminals had baseline membrane capacitance measurements of 9-15 and 3-7 pF, respectively. Only isolated terminals were used for this study.

Dissociated bipolar cell terminal preparation. Goldfish retinal bipolar cells were acutely isolated as described previously (Heidelberger and Matthews, 1992). In brief, pieces of isolated retina were treated with hyaluronidase ( $1 \mathrm{mg}$ in $1 \mathrm{ml}$ of medium) (Sigma, St. Louis, MO) to remove vitreous humor, followed by treatment with papain (10 $\mathrm{mg}$ in 1 $\mathrm{ml}$ of medium) (Fluka, Milwaukee, WI) and mechanical dissociation with a small-bore Pasteur pipette. Cells were plated and viewed with DIC optics through a $40 \times$ water-immersion objective and $1.6 \times$ zoom tube (Axioskop; Zeiss), and a CCD camera (Hamamatsu). Isolated bipolar cell terminals were identified by their size and shape, as well as depolarization-evoked $\mathrm{Ca}^{2+}$ currents and capacitance responses. Recordings were made in extracellular medium comprising (in $\mathrm{mM}$ ): 120 $\mathrm{NaCl}, 2.5 \mathrm{KCl}, 1.0 \mathrm{MgCl}_{2}, 2.5 \mathrm{CaCl}_{2}, 10$ HEPES, 12 glucose, adjusted to desired $\mathrm{pH}$ with $\mathrm{NaOH}, \sim 260 \mathrm{mOsm}$. Cells were dissociated in low $\mathrm{Ca}^{2+}$ solution $(0.5 \mathrm{~mm})$. Bath solution was exchanged at a continuous rate of $3-4 \mathrm{ml} / \mathrm{min}$. Recordings were made at room temperature $\left(22-24^{\circ} \mathrm{C}\right)$.

Electrophysiology. Whole-cell voltage-clamp recordings were obtained using 5-8 $\mathrm{M} \Omega$ patch pipettes pulled from thick-walled borosilicate glass (World Precision Instruments, Sarasota, FL) using a Narishige puller (model PP-830). Pipettes were coated with wax to reduce pipette capacitance and electrical noise and filled with solution comprising (in $\mathrm{mM}$ ): 115 Cs gluconate, 25 HEPES, 10 TEA-Cl, 3 Mg-ATP, 0.5 Na-GTP, 0.5 EGTA, adjusted to $\mathrm{pH} 7.2$ with $\mathrm{CsOH}, \sim 270$ mOsm. Cs gluconate was replaced with $\mathrm{CsCl}$ for high intracellular $\mathrm{Cl}^{-}$recordings. After gaining whole-cell access, series resistance was typically $10-15 \mathrm{M} \Omega$, and leak current was $<50 \mathrm{pA}$ at a holding potential of $-60 \mathrm{mV}$. Data acquisition was controlled by "Pulse" software (Heka, Lambrecht, Germany), and signals were recorded via a double EPC-9 (Heka) patch-clamp amplifier. Sampling rates and filter settings were 10 and $3 \mathrm{kHz}$, respectively. Capacitance measurements were performed by the "sine + DC" method. In brief, a $1 \mathrm{kHz}$ sinusoidal voltage command ( $30 \mathrm{mV}$ peak to peak) was added to the holding potential of $-60 \mathrm{mV}$, and the resulting current was analyzed at two orthogonal phase angles by the EPC-9 lock-in amplifier. These signals, together with the DC current, were used to generate values for membrane capacitance, membrane conductance, and series conductance (Gillis, 2000). Off-line analysis was performed with "IgorPro" software (Wavemetrics, Lake Oswego, OR).

Analysis. Pooled data are expressed as mean \pm SEM. Statistical significance was assessed with paired and unpaired Student's $t$ tests as appropriate, with $p<0.05$ considered significant. The increase in membrane capacitance, $\Delta C_{\mathrm{m}}$, evoked by membrane depolarization, was measured

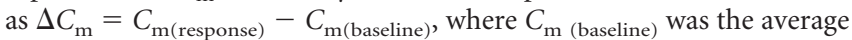
$C_{\mathrm{m}}$ value during the $100 \mathrm{msec}$ before the depolarizing step, and $C_{\mathrm{m}}$ (response) was the average $C_{\mathrm{m}}$ value measured over 50 or $100 \mathrm{msec}$ after the step, starting $40 \mathrm{msec}$ after repolarization to allow time for all evoked conductances to have decayed.

For assessment of the effect of extracellular $\mathrm{pH}$ on $\mathrm{Ca}^{2+}$ currents in dissociated bipolar cell terminals, voltage ramps from -60 to $+50 \mathrm{mV}$ and voltage steps from -60 to $0 \mathrm{mV}$ were delivered before and after changing the bath solution from $\mathrm{pH} 7.5$ to a test $\mathrm{pH}$ between 6.0 and 8.0 and back to $\mathrm{pH}$ 7.5. Recorded currents were leak-subtracted by a standard $\mathrm{P} / 4$ protocol, which did not introduce noticeable changes to $\mathrm{Ca}^{2+}$ current kinetics or current-voltage $(I-V)$ relationship. For cells that exhibited $\mathrm{Ca}^{2+}$ current rundown, a correction factor was applied to the test $\mathrm{pH}$ currents that was derived from a linear extrapolation of the $\mathrm{Ca}^{2+}$ current rundown from its initial to final amplitude in $\mathrm{pH}$ 7.5. Normalized $\mathrm{Ca}^{2+}$ current activation curves were obtained by dividing the mean $I-V$ relationship for each $\mathrm{pH}$ by the $\mathrm{Ca}^{2+}$ driving force $\left(V-V_{\text {rev }}\right)$ according to Ohm's law, where $V_{\text {rev }}$ is the reversal potential for the $\mathrm{Ca}^{2+}$ current. These activation curves were then best fit (using IgorPro software) with a normalized Boltzmann function $F(V)=A /\{1+\exp [-(V-$ $\left.\left.\left.V_{1 / 2}\right) / m\right]\right\}$, where $A$ (set to 1 in the normalized curves), $V_{1 / 2}$ (the midpoint voltage), and $m$ (the slope factor: $m=k T / z e$ ) are fitting constants. With $T=22-24^{\circ} \mathrm{C}$ (room temperature), the value of $k T / e$ was $\sim 25.5 \mathrm{mV}$. The fit parameter $m$ varied from 6.57 to $5.23 \mathrm{mV}$, so $z$ (the valence of the gating charge) varied from 3.9 to 4.9. Fits to the Hill equation were done using IgorPro software and the function $F(\mathrm{pH})=$ Base $+(\mathrm{Max}-$ Base $\left.) /\left[1+\mathrm{pH}_{1 / 2} / \mathrm{pH}\right)^{\mathrm{n}}\right]$. In Figure $6 b$, the values for the solid line $(0 \mathrm{mV})$ of Base, $\mathrm{Max}, n$, and $\mathrm{pH}_{1 / 2}$ are $0.18,1.9,11.6$, and 7.6, and for the dashed line $(-10 \mathrm{mV})$ they are $0.017,1.3,26$, and 7.2 , respectively.

Drug application. Drugs were bath applied in the perfusing medium. 2,3-Dioxo-6-nitro-1,2,3,4-tetrahydrobenzo[f]quinoxaline-7-sulfonamide (NBQX), DL-2-amino-5-phosphonopentanoic acid (DL-AP5), and DLthreo- $\beta$-benzyloxyaspartate (TBOA) were obtained from Tocris (Bristol, UK). Picrotoxin, strychnine, and all other chemicals and salts were obtained from Sigma.

\section{Results}

\section{Paired-pulse depression of exocytosis in bipolar cells}

Goldfish retina contains a class of bipolar cells that depolarize to light (ON-type) and have an unusually large synaptic terminal (Witkovsky and Dowling, 1969; Saito and Kujiraoka, 1982). These cells have been classified morphologically as mixed bipolar $(\mathrm{Mb})$ cells because they receive both rod and cone input. The $\mathrm{Mb}$ cell synaptic terminal (8-15 $\mu \mathrm{m}$ in diameter) (Ishida et al., 1980; Sherry and Yazulla, 1993) contains a large number of glutamatergic synaptic vesicles (500,000-750,000) (von Gersdorff et al., 
a

\section{Dissociated terminal}

I

C $\mathrm{I}_{\mathrm{Ca}}$ superimposed
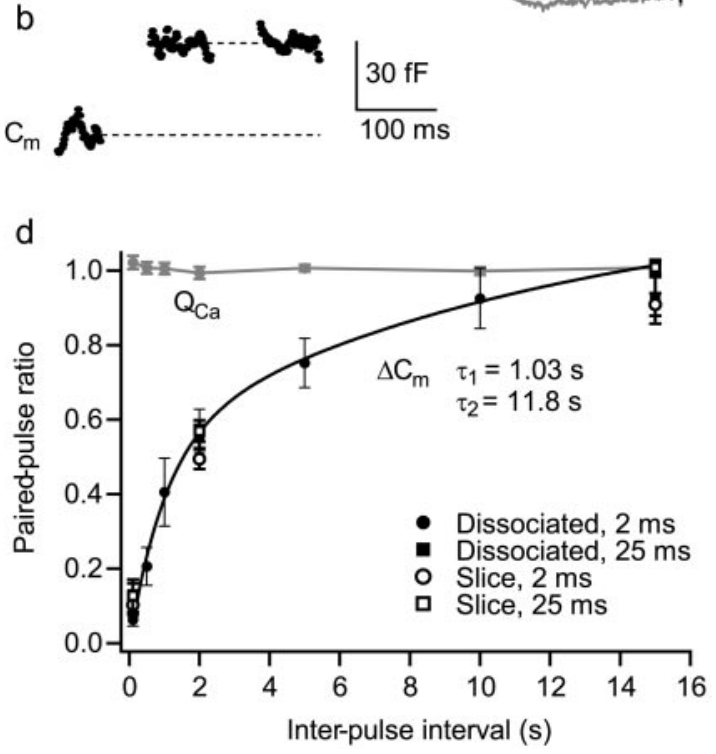

Figure 1. Paired-pulse depression of exocytosis in bipolar cells. $a$, The membrane current evoked by a pair of $25 \mathrm{msec}$ voltage steps from -60 to $-10 \mathrm{mV}$ ( $100 \mathrm{msec}$ interval) in a dissociated isolated terminal. Rapidly activating, nondesensitizing inward $\mathrm{Ca}^{2+}$ currents $\left(I_{\mathrm{Ca}}\right)$ were evoked. The fast voltage sinewave used to measure membrane capacitance $\left(C_{m}\right)$ was not delivered during the depolarizations. The intracellular solution contained Cs gluconate; the extracellular solution contained $12 \mathrm{~mm}$ HEPES. $b$, The corresponding $C_{m}$ trace for the terminal in a. $\Delta C_{m}$ was evoked by the first depolarization but not the second; the terminal exhibited strong paired-pulse depression of exocytosis. Baseline $C_{m}$ for this terminal was $4.2 \mathrm{pF}$. $C_{\text {, First and }}$ second pulse $I_{\mathrm{Ca}}$ superimposed on an expanded time scale (first black, second gray; also applies to subsequent figures). $d$, Mean paired-pulse ratio (second pulse/first pulse) of $\Delta C_{\mathrm{m}}$ and $\mathrm{Ca}^{2+}$ influx $\left(Q_{\mathrm{Ca}}\right)$ for pairs of $2 \mathrm{msec}$ depolarizations in dissociated terminals with interpulse intervals ranging from $100 \mathrm{msec}$ to $15 \mathrm{sec}$. Each point is an average of values from at least six terminals. The black line is a bi-exponential fit of the $\Delta C_{\mathrm{m}}$ ratio values with time constants of $1.03 \mathrm{sec}$ (43\%) and $11.8 \mathrm{sec}(57 \%)$. Also shown are the mean $\Delta C_{m}$ ratios with interpulse intervals of 100 $\mathrm{msec}, 2 \mathrm{sec}$, and $15 \mathrm{sec}$ for pairs of $25 \mathrm{msec}$ depolarizations in dissociated terminals, and for both 2 and 25 msec depolarizations in terminals in retinal slices $(n=4-16)$. The magnitude and rate of recovery from depression were similar under all conditions.

1996) and displays a slowly inactivating L-type $\mathrm{Ca}^{2+}$ current (Heidelberger and Matthews, 1992). $\mathrm{Ca}^{2+}$ influx through L-type channels triggers exocytosis of synaptic vesicles (Tachibana et al., 1993) that can be measured as an increase in terminal membrane capacitance $\left(\Delta C_{\mathrm{m}}\right)$ (von Gersdorff and Matthews, 1994).

To identify $\mathrm{Ca}^{2+}$ current inhibition associated with exocytosis, the pronounced paired-pulse depression of exocytosis exhibited by $\mathrm{Mb}$ cells was exploited. Paired-pulse depression in dissociated terminals is not caused by depression of $\mathrm{Ca}^{2+}$ influx and requires $\sim 15 \mathrm{sec}$ for full recovery (von Gersdorff and Matthews, 1997; Gomis et al., 1999). An example is shown in Figure $1 a$ of the membrane current and capacitance responses to a pair of $25 \mathrm{msec}$ depolarizations from -60 to $-10 \mathrm{mV}$, with an interpulse interval of $100 \mathrm{msec}$. The first depolarization evoked an inward $\mathrm{Ca}^{2+}$ current $\left(I_{\mathrm{Ca}}\right)($ Fig. $1 a, c)$ and $\Delta C_{\mathrm{m}}$ (Fig. 1b), whereas the second depolarization evoked $I_{\mathrm{Ca}}$ of similar magnitude (Fig. $1 a, c$ ) but no $\Delta C_{\mathrm{m}}$ (Fig. 1b), reflecting depression of exocytosis. The amount of depression was reduced as the interpulse interval increased, as shown in Figure $1 d$. Mean paired-pulse ratio (second pulse/first pulse) was measured for pulses of 2 and $25 \mathrm{msec}$ duration in both acutely dissociated terminals and terminals embedded in retinal slices. A bi-exponential best-fit of the dissociated terminal $2 \mathrm{msec}$ pulse data gives recovery time constants of 1.03 and $11.8 \mathrm{sec}$. Very similar rates of recovery from paired-pulse depression were observed with 2 and $25 \mathrm{msec}$ pulses and between dissociated terminals and terminals in retinal slices (Fig. 1d).

Paired-pulse depression is most readily explained by the selective depletion of vesicles docked close to $\mathrm{Ca}^{2+}$ channels (Burrone and Lagnado, 2000) and can be overcome by increasing $\mathrm{Ca}^{2+}$ influx to access more distant vesicles. For example, a stimulation protocol comprising a pair of $2 \mathrm{msec}$ depolarizations followed by a 25 msec depolarization (100 msec intervals) evokes mean $\Delta C_{\mathrm{m}}$ values of $56 \pm 5,6 \pm 1$, and $18 \pm 4 \mathrm{fF}$, respectively $(n=7$ dissociated terminals). The total amount of release to this proto$\operatorname{col}(80 \pm 7 \mathrm{fF})$ is not significantly different from that evoked by a single $25 \mathrm{msec}$ depolarization delivered $20 \mathrm{sec}$ later $(77 \pm 7 \mathrm{fF}$; $n=7$ ), suggesting that these stimuli access the same total pool of vesicles. These data are also inconsistent with a refractory period or adaptation process causing depression after release, as has been suggested to occur at some synapses (Korn et al., 1984; Hsu et al., 1996; Bellingham and Walmsley, 1999). A bi-exponential recovery from paired-pulse depression has also been observed in hair cells (Moser and Beutner, 2000), which also have synaptic ribbons. Interestingly, a recent study of ON-EPSCs in retinal ganglion cells that were evoked by paired pulses of light also shows a bi-exponential recovery from paired-pulse depression with a remarkably similar time course (e.g., $\approx 80 \%$ recovery after $5 \mathrm{sec}$ ) (Akopian, 2003).

\section{$\mathrm{Ca}^{2+}$ current inhibition is associated with exocytosis in retinal slices}

$I_{\mathrm{Ca}}$ evoked by the first and second depolarizations of a pair were compared to investigate differences associated with exocytosis. In dissociated terminals, the second $I_{\mathrm{Ca}}$ was sometimes observed to be slightly larger than the first (Fig. 1c). In terminals in retinal slices, however, the difference was much more pronounced. A transient upward deflection was consistently observed during the first $I_{\mathrm{Ca}}$ that was not present during the second $I_{\mathrm{Ca}}$ (Fig. 2c). This upward deflection was isolated as a difference current by subtraction of the second from the first $I_{\mathrm{Ca}}$ (Fig. $2 d$ ). It was observed in the presence of antagonists of ionotropic GABA (50 $\mu \mathrm{M}$ picrotoxin), glycine (1 $\mu \mathrm{M}$ strychnine), and glutamate (5-10 $\mu \mathrm{M}$ NBQX, $100 \mu \mathrm{M}$ DL-AP5) receptors $(n=12)$, which block activation of reciprocal inhibitory amacrine cell synapses (Hartveit, 1999). The upward deflection was also insensitive to the glutamate transporter inhibitor TBOA (30-100 $\mu \mathrm{M}, n=9)$ (Fig. 2e) and unaffected by bath perfusion of a high concentration of L-glutamate ( $1 \mathrm{~mm} ; n=4)$ or reversal of the $\mathrm{Cl}^{-}$gradient across the terminal membrane ( $20 \mathrm{~mm}$ extracellular, $125 \mathrm{~mm}$ intracellular; $n=8$ ) (Fig. 2f). The upward deflection is therefore not a glutamate- or GABA-evoked current or other $\mathrm{Cl}^{-}$conductance and is most likely to reflect transient inhibition of $I_{\mathrm{Ca}}$, similar to that reported by DeVries (2001) in photoreceptors. The inhibition appears to be associated with exocytosis because of the correlation with $\Delta C_{\mathrm{m}}$ during paired-pulse stimulation. A similar correlation was found by DeVries (2001) between cone $\mathrm{Ca}^{2+}$ current inhibition and the postsynaptic bipolar cell response. The size of the cone difference current and the bipolar cell response recovered from paired-pulse depression with a similar time course. 

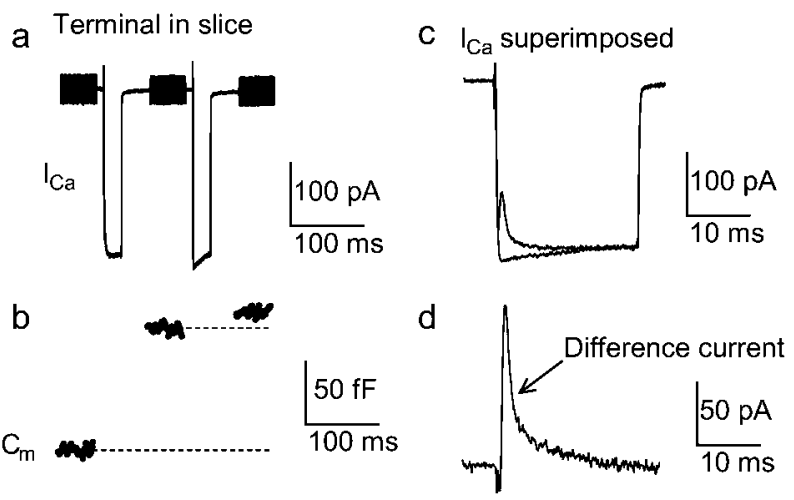

e TBOA
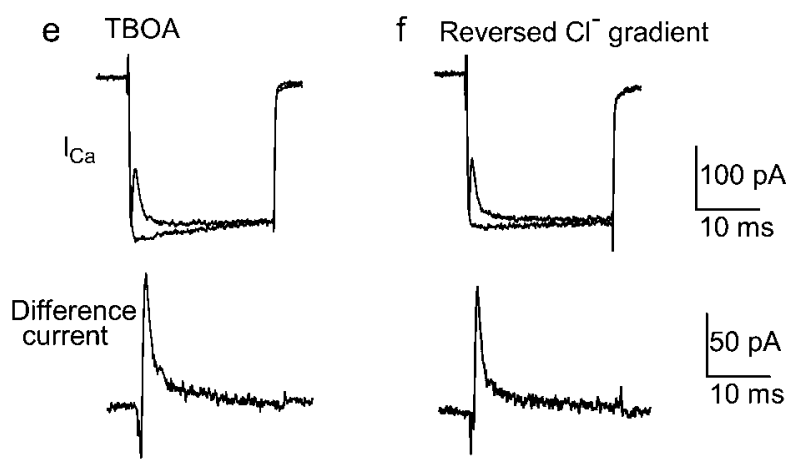

Figure 2. $I_{\mathrm{Ca}}$ in bipolar cell terminals exhibits an outward component associated with exocytosis. $a, I_{C a}$ evoked by a pair of $25 \mathrm{msec}$ voltage steps from -60 to $-10 \mathrm{mV}(100 \mathrm{msec}$ interval) in a terminal in a retinal slice. The intracellular solution contained (s gluconate; the extracellular solution contained $50 \mu \mathrm{m}$ picrotoxin, $1 \mu \mathrm{m}$ strychnine, $5 \mu \mathrm{M}$ NBQX, $100 \mu \mathrm{m}$ DLAP5, and 12 mM HEPES. $b, \Delta C_{\mathrm{m}}$ evoked by the depolarizations in $a$, showing paired-pulse depression. $c$, The first and second pulse $I_{C_{a}}$ from a superimposed on an expanded time-scale. A transient outward component was observed during the first but not the second current. $d$, The difference current obtained by subtracting second pulse $I_{\mathrm{Ca}_{\mathrm{a}}}$ from first pulse $I_{\mathrm{Ca}} \cdot e$, Superimposed first and second pulse $I_{\mathrm{Ca}_{\mathrm{a}}}$ and difference current obtained as above but for a terminal with $30 \mu \mathrm{m}$ TBOA added to the extracellular solution. The difference current is not caused by glutamate transporter activation. $f$, The first and second pulse $I_{\mathrm{Ca}}$ and difference current obtained as above but for a terminal with a reversed $\mathrm{Cl}^{-}$gradient across the membrane ( $20 \mathrm{~mm}$ extracellular, 125 $\mathrm{mm}$ intracellular). The difference current is not mediated by a $\mathrm{Cl}^{-}$channel. It is most likely to result from a transient inhibition of $I_{\text {ca. }}$.

The relationship between $I_{\mathrm{Ca}}$ inhibition and exocytosis was further tested by using the rundown in exocytosis that occurs during the course of whole-cell recordings from bipolar cell terminals (Palmer et al., 2003). Pairs of 25 msec depolarizations ( 100 msec interval) were delivered to terminals every $20 \mathrm{sec}$. For each pair of stimuli, the size of the upward deflection $\left(I_{\text {inhibition }}\right)$ was measured as the peak of the difference current (Fig. $3 a, b$ ) and compared with first pulse $\Delta C_{\mathrm{m}}$ (Fig. $3 c$ ). In all terminals, $I_{\text {inhibition }}$ as well as $\Delta C_{\mathrm{m}}$ gradually decreased during the recording, and the rate of rundown was very similar for both parameters (Fig. $3 d$ ). Thus, after $280 \mathrm{sec}, \Delta C_{\mathrm{m}}$ was $22 \pm 8 \%$ and $I_{\text {inhibition }}$ was $10 \pm 6 \%$ of the value evoked by the first stimulus $(n=5)$. Inhibition of $I_{\mathrm{Ca}}$ and exocytosis are therefore correlated over both short and long time periods. Interestingly, recordings of $\mathrm{Ca}^{2+}$ currents in mammalian cones in intact retina show a very similar inhibitory component that disappears after $\sim 5$ min of whole-cell dialysis (Taylor and Morgans, 1998).

Comparison of $I_{\text {inhibition }}$ time course with rate of exocytosis If inhibition of $I_{\mathrm{Ca}}$ is occurring as a consequence of exocytosis, the two processes should occur sequentially with a similar time

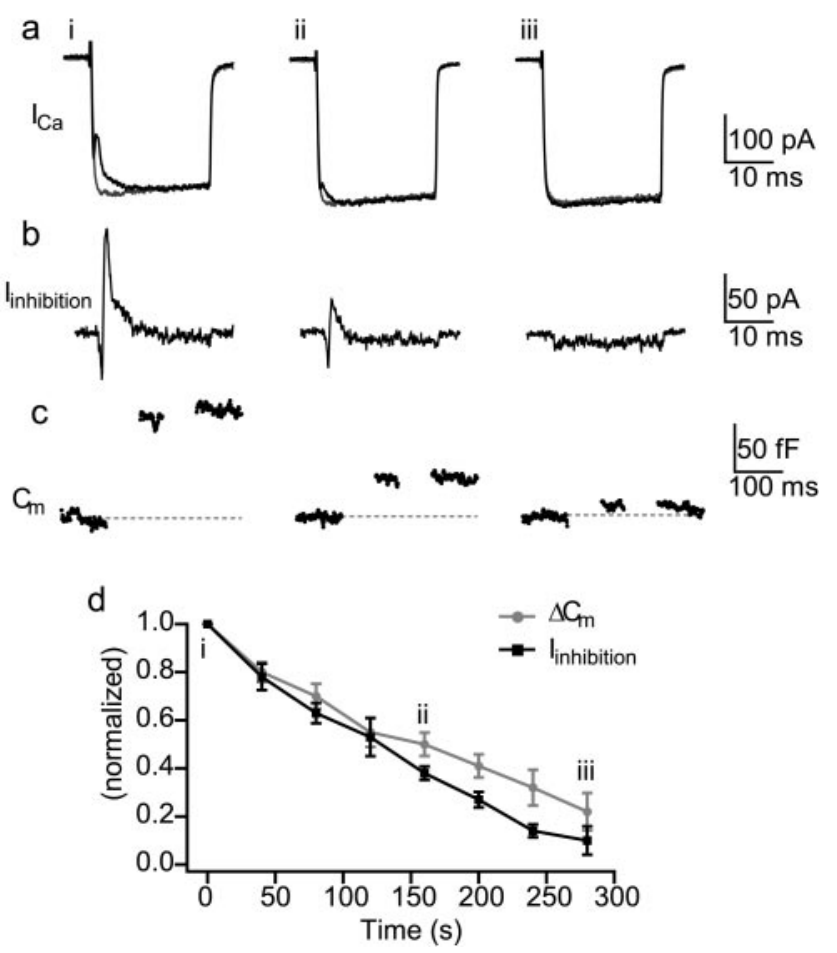

Figure 3. Correlated rundown of $I_{\text {inhibition }}$ and $\Delta C_{m}$ during recordings from bipolar cell terminals. a, Paired $25 \mathrm{msec}$ depolarizations taken from three time points during a recording. First and second pulse $I_{\mathrm{Ca}_{\mathrm{a}}}$ are superimposed. The extracellular solution contained $12 \mathrm{~mm}$ HEPES. $b$, $I_{\text {inhibition }}$, obtained by subtracting second pulse from first pulse $I_{\mathrm{Ca}}$, for the depolarizations in $a$. $l_{\text {inhibition }}$ decreases during the recording. $d, \Delta C_{m}$ evoked by the paired depolarizations in $a$. First pulse $\Delta C_{\mathrm{m}}$ decreases during the recording. $e$, Mean first pulse $\Delta C_{\mathrm{m}}$ (gray circles) and $I_{\text {inhibition }}$ (black squares), normalized to the first stimulus, during the course of five recordings. $\Delta C_{\mathrm{m}}$ and $I_{\text {inhibition }}$ run down at a very similar rate. The labels $\mathrm{i}$, ii, and iii relate the currents in $a$ with the time points in $d$.

course during the depolarization. DeVries (2001) observed that the cone difference current had kinetics similar to the postsynaptic bipolar cell response. In bipolar cell terminals, the rate of exocytosis can be measured more directly with $\Delta C_{\mathrm{m}}$. First, the time course of $I_{\mathrm{Ca}}$ inhibition was determined. Pairs of $25 \mathrm{msec}$ depolarizations to $-10 \mathrm{mV}$ were delivered in the presence of ionotropic GABA, glycine, and glutamate receptor antagonists (50 $\mu \mathrm{M}$ picrotoxin, $1 \mu \mathrm{M}$ strychnine, $10 \mu \mathrm{M}$ NBQX, $100 \mu \mathrm{M}$ DLAP5) and the glutamate transporter inhibitors TBOA $(30 \mu \mathrm{M})$ or DL-threo-3-hydroxyaspartate (THA) $(300 \mu \mathrm{M}) . I_{\text {inhibition }}$ was obtained by subtracting the second pulse from first pulse $I_{\mathrm{Ca}}$ and averaged for four terminals (Fig. $4 a$ ). In a different set of slice terminals, the rate of release during a $25 \mathrm{msec}$ depolarization to $-10 \mathrm{mV}$ was calculated from the $\Delta C_{\mathrm{m}}$ evoked by depolarizations of $1,2,5,10$, and $50 \mathrm{msec}$ duration (Fig. 4b). Release rate and $I_{\text {inhibition }}$ during the depolarization were then compared (Fig. 4c). Release rate was greatest during the first milliseconds and then decreased with a time constant of $1.04 \mathrm{msec}$ (Fig. 4c), which is similar to previous findings ( $1.5 \mathrm{msec}$ for steps to $0 \mathrm{mV}$ ) (Mennerick and Matthews, 1996). The peak of $I_{\text {inhibition }}$ occurred within 2 msec of the start of the depolarization, and the decay was well fit by a double-exponential function with time constants of $0.73 \mathrm{msec}(68 \%)$ and $7.6 \mathrm{msec}(32 \%)$ (Fig. $5 c$ ). The onset of the inhibition of $I_{\mathrm{Ca}}$ was therefore similar to the initial rate of exocytosis from the terminal, with a delay of $\sim 1 \mathrm{msec}$. The fast decay time constant of $I_{\text {inhibition }}$, i.e., fast recovery of $I_{\mathrm{Ca}}$, was similar to the decrease in the rate of exocytosis during the depolarization. 

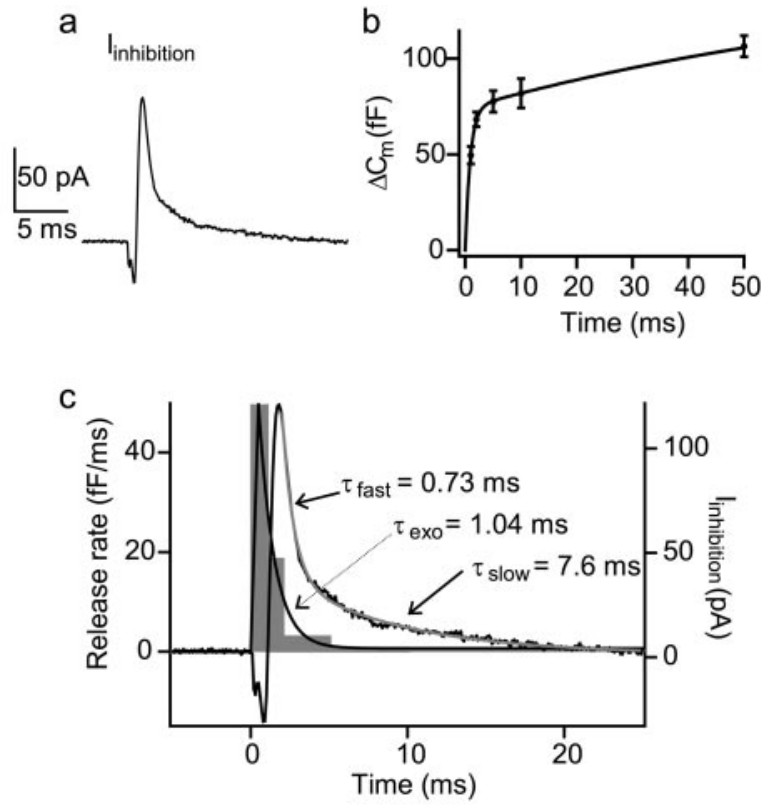

Figure 4. Time course of exocytosis and $I_{\text {inhibition }}$ during a depolarization. $a, M e a n I_{\text {inhibition }}$ ( $n=4$ terminals) obtained from paired $25 \mathrm{msec}$ depolarizations in the presence of $50 \mu \mathrm{M}$ picrotoxin, $1 \mu \mathrm{m}$ strychnine, $5 \mu \mathrm{m} \mathrm{NBQX,} 100 \mu \mathrm{m} \mathrm{DL}-\mathrm{AP} 5,30 \mu \mathrm{m}$ TBOA/300 $\mu \mathrm{m}$ THA, and $12 \mathrm{~mm}$ HEPES. $b$, Mean $\Delta C_{\mathrm{m}}$ evoked by $1,2,5,10$, and $50 \mathrm{msec}$ depolarizations from -60 to $-10 \mathrm{mV}$, in a different set of slice terminals $(n=9)$. Solid line is a double exponential best fit of the data. c, Rate of exocytosis during a 25 msec depolarization, obtained from points in $b$ and fit with a single exponential, plotted with / inhibition from $a$, for comparison of time course. The rise and fast decay time constant $\left(\tau_{\text {fast }}\right)$ of $I_{\text {inhibition }}$ were similar to the rise and decay $\left(\tau_{\text {exo }}\right)$ of release rate, but the decay of $/_{\text {inhibition }}$ also exhibited a slower component $\left(\tau_{\text {slow }}\right)$.

The degree of $I_{\mathrm{Ca}}$ inhibition may therefore be tightly linked to the rate of exocytosis; however, the slow decay time constant indicates that an additional process delays the recovery of $I_{\mathrm{Ca}}$. The reason for the initial downward deflection of $I_{\text {inhibition }}$ is currently unknown.

\section{$I_{\mathrm{Ca}}$ inhibition is modulated by extracellular $\mathrm{pH}$ buffer}

The inhibition of $I_{\mathrm{Ca}}$ recently described in photoreceptors (DeVries, 2001) was greatly reduced by addition of the $\mathrm{pH}$ buffer HEPES (20 mM) to the extracellular medium. We therefore investigated the effect of changing the HEPES concentration on $I_{\mathrm{Ca}}$ in bipolar cell terminals. Pairs of $25 \mathrm{msec}$ depolarizations to -10 $\mathrm{mV}$ were delivered in the presence of 3 or $48 \mathrm{~mm}$ extracellular HEPES (Fig. 5a,b) (standard solution contained 12 mM HEPES; $\mathrm{pH}$ and osmolarity were maintained between solutions). Because of the effects of rundown, only the first few responses obtained after gaining whole-cell access were compared between terminals. The HEPES concentration had no direct effect on $\mathrm{Ca}^{2+}$ influx because the average amplitude of second pulse $I_{\mathrm{Ca}}$ was not significantly different in $3 \mathrm{mM}(188 \pm 13 \mathrm{pA} ; n=5)$ and $48 \mathrm{mM}$ $(211 \pm 16 \mathrm{pA} ; n=6)$ HEPES. In addition, the average $\Delta C_{\mathrm{m}}$ evoked by the first pulse was not significantly different in $3 \mathrm{mM}$ $(57 \pm 9 \mathrm{fF} ; n=5)$ and $48 \mathrm{~mm}(54 \pm 9 \mathrm{fF} ; n=6)$ HEPES. However, changing the extracellular HEPES concentration had a dramatic effect on the first pulse inhibition of $I_{\mathrm{Ca}}$ (Fig. 5c). The amount of inhibition $\left(Q_{\text {inhibition }}\right)$ was quantified by subtracting first pulse from second pulse $\mathrm{Ca}^{2+}$ charge. $Q_{\text {inhibition }}$ was $264 \pm 22 \mathrm{fC}$ in standard $12 \mathrm{~mm}$ HEPES $(n=8), 73 \pm 22 \mathrm{fC}$ in $48 \mathrm{~mm}$ HEPES $(n=6 ; p<0.05)$, and $805 \pm 192 \mathrm{fC}$ in 3 mM HEPES $(n=5 ; p<$ 0.05 ) (Fig. $5 d$ ). This sensitivity to extracellular HEPES is consis-

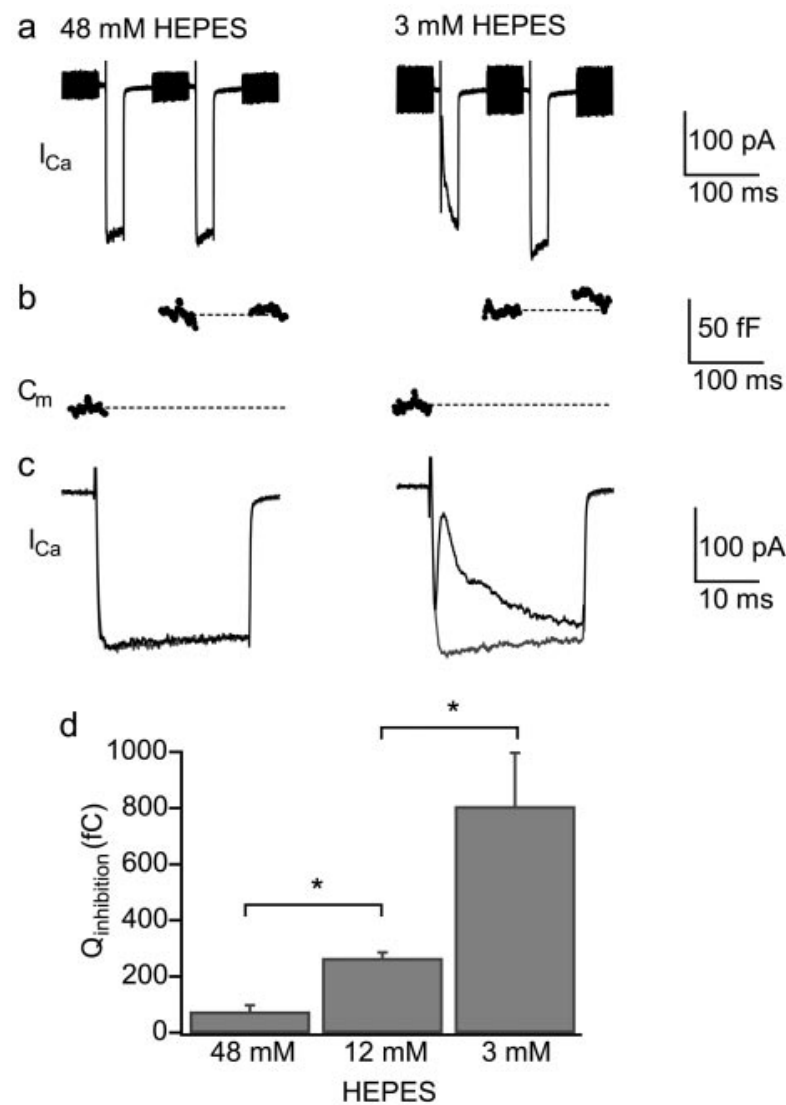

Figure 5. Modulation of $l_{\text {inhibition }}$ by extracellular $\mathrm{pH}$ buffer. $a, I_{\mathrm{Ca}_{\mathrm{C}}}$ evoked by a pair of $25 \mathrm{msec}$ depolarizations to $-10 \mathrm{mV}$ (100 msec interval) in two terminals, in the presence of a fourfold higher ( $48 \mathrm{~mm}$ ) or fourfold lower ( $3 \mathrm{~mm}$ ) than standard concentration of extracellular HEPES. $b$, $\Delta C_{\mathrm{m}}$ evoked by the depolarizations in $a$. A similar amount of exocytosis was observed in 3 and

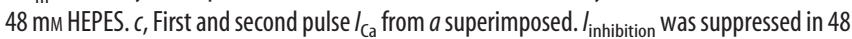
mм HEPES but greatly potentiated in 3 mM HEPES. $d$, Mean $Q_{\text {inhibition }}$ (second pulse $\mathrm{Ca}^{2+}$ charge minus first pulse $\mathrm{Ca}^{2+}$ charge) in the presence of $48 \mathrm{~mm}(n=6), 12 \mathrm{~mm}(n=8)$, and $3 \mathrm{~mm}(n=$ 5) extracellular HEPES. (Error bars represent SEM. ${ }^{*} p<0.05$ ).

tent with inhibition of $I_{\mathrm{Ca}}$ in bipolar cell terminals by a transient increase in extracellular proton concentration after exocytosis.

\section{Extracellular acidification inhibits $I_{\mathrm{Ca}}$}

To determine the $\mathrm{pH}$ sensitivity of voltage-gated $\mathrm{Ca}^{2+}$ channels in bipolar cell terminals, $I_{\mathrm{Ca}}$ was recorded in dissociated terminals in the presence of extracellular solutions of varying $\mathrm{pH}$. Step depolarizations $(200 \mathrm{msec})$ to $0 \mathrm{mV}$ were delivered at $\mathrm{pH} 7.5$ and compared with $\mathrm{pH} 6.0,6.5,7.0$, or 8.0 in the same terminal by fast exchange of bath solution, followed by a return to $\mathrm{pH} 7.5$ (Fig. $6 a) . I_{\mathrm{Ca}}$ amplitude was found to be strongly $\mathrm{pH}$ dependent, with acidification from $\mathrm{pH} 7.5$ to 6.0 causing inhibition of $71 \pm 3 \%$ $(n=5)$ (Fig. 6b). The effect of $\mathrm{pH}$ on the voltage sensitivity of $I_{\mathrm{Ca}}$ was assessed using voltage ramps from -60 to $+50 \mathrm{mV}$ in the presence of extracellular solutions of varying $\mathrm{pH}$. Both $I_{\mathrm{Ca}}$ activation and the peak current were shifted to more positive potentials in low $\mathrm{pH}$ solution (Fig. $6 c$ ). The mean $I-V$ relationships obtained at each $\mathrm{pH}$ were used to generate normalized activation curves and fit with a Boltzmann function (Fig. $6 d$ ). The halfactivation voltages revealed that acidification from $\mathrm{pH} 7.5$ to 6.0 caused a $+25 \mathrm{mV}$ shift in $\mathrm{Ca}^{2+}$ channel activation [pH 7.5: -16 $\mathrm{mV}(n=10) ; \mathrm{pH} 6.0:+9 \mathrm{mV}(n=4)]$. Thus, bipolar cell terminal $\mathrm{Ca}^{2+}$ currents are highly sensitive to changes in extracellular $\mathrm{pH}$. 

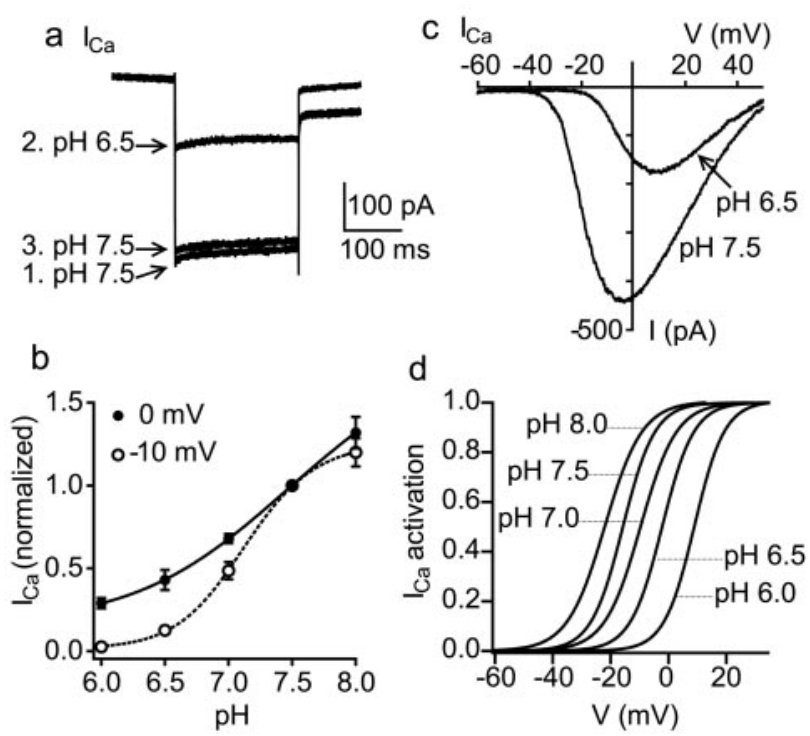

Figure 6. pH sensitivity of $I_{\mathrm{Ca}_{\mathrm{a}}}$ in bipolar cell terminals. $a, I_{\mathrm{Ca}_{\mathrm{a}}}$ evoked by $200 \mathrm{msec}$ depolarizations from -60 to $0 \mathrm{mV}$ in a dissociated bipolar cell terminal. Extracellular pH was changed from 7.5 to 6.5 and back to control via a complete exchange of the bath solution. Currents are leak subtracted. The small inward current observed after repolarization is caused by activation of $\mathrm{Ca}^{2+}$-dependent $\mathrm{Cl}^{-}$channels (Okada et al., 1995). b. Solid symbols indicate mean $I_{\text {Ca }}$ amplitude evoked by depolarizations to $0 \mathrm{mV}$ as a function of $\mathrm{pH}$. Each measurement was normalized to the current at $\mathrm{pH} 7.5$ and corrected for rundown of $I_{\mathrm{Ca}}$ during the experiment ( $n=3-7$ for each point; error bars represent SEM). Data were fit with a Hill equation $\left(\mathrm{pH}_{1 / 2}=\right.$ 7.6). Open symbols indicate mean $I_{\mathrm{Ca}}$ amplitude evoked by depolarizations to $-10 \mathrm{mV}$, obtained from the $I-V$ relationship at each $\mathrm{pH}$ (no leak subtraction; $n=3-4$ for each point). Data were fit with a Hill equation $\left(\mathrm{pH}_{1 / 2}=7.2\right) . \mathrm{C}, \mathrm{I}_{\mathrm{Ca}} \mathrm{I}-\mathrm{V}$ relationship measured with a depolarizing ramp from -60 to $+50 \mathrm{mV}$ in the same terminal as $a$ at $\mathrm{pH} 7.5$ and 6.5. $I_{\mathrm{Ca}}$ activation is shifted to a more positive potential at lower $\mathrm{pH}$. Note the smooth rise in the $I-V$ curve at negative potentials indicating good voltage-clamp control of the terminal. $d$, Boltzmann-fit activation curves derived from the average $I-V$ relationships at each $\mathrm{pH}$. Half-activation potentials of these curves are $-22 \mathrm{mV}(\mathrm{pH} 8.0 ; n=4),-16 \mathrm{mV}(\mathrm{pH} 7.5 ; n=10),-10 \mathrm{mV}(\mathrm{pH} 7.0 ; n=3),-2$ $\mathrm{mV}(\mathrm{pH} 6.5 ; n=2)$, and $9 \mathrm{mV}(\mathrm{pH} 6.0 ; n=4)$.

\section{Extracellular HEPES modulates paired-pulse depression of release}

To determine whether inhibition of $I_{\mathrm{Ca}}$ by released vesicular protons causes subsequent inhibition of exocytosis from the terminal, brief depolarizations were used to maximize the degree of inhibition. The average $\Delta C_{\mathrm{m}}$ evoked by a $2 \mathrm{msec}$ depolarization was measured in the presence of 3 or $48 \mathrm{~mm}$ extracellular HEPES. The amount of exocytosis in 3 mM HEPES ( $23 \pm 3 \mathrm{fF} ; n=8)$ tended to be less than in $48 \mathrm{~mm} \operatorname{HEPES}(31 \pm 4 \mathrm{fF} ; n=8)$, but this difference was not significant. It is likely that the variability in depolarization-evoked $\Delta C_{\mathrm{m}}$ between terminals makes it difficult to detect subtle effects of HEPES. Paired-pulse depression of release was therefore used as a more sensitive measure of exocytosis.

Paired-pulse depolarizations of 2, 5, and $10 \mathrm{msec}$ duration (100 msec interval) were delivered in the presence of 3 or $48 \mathrm{mM}$ extracellular HEPES. The $\mathrm{Ca}^{2+}$ charge $\left(Q_{\mathrm{Ca}}\right)$ ratio and $\Delta C_{\mathrm{m}}$ ratio (second pulse/first pulse) were measured for each pair of pulses. In $48 \mathrm{~mm} H E P E S$, the $Q_{\mathrm{Ca}}$ ratio was close to 1 for all pulse durations (2 msec: $1.03 \pm 0.01 ; 5$ msec: $1.05 \pm 0.01 ; 10$ msec: $1.04 \pm$ $0.01 ; n=8)$ because there was little inhibition of first pulse $I_{\mathrm{Ca}}$ (Fig. $7 a, e)$. The $\Delta C_{\mathrm{m}}$ ratio was close to zero ( $2 \mathrm{msec}: 0.11 \pm 0.02$; 5 msec: $0.06 \pm 0.02 ; 10$ msec: $0.05 \pm 0.03 ; n=8)$, reflecting almost complete depression of release to the second pulse (Fig. $7 b, f)$. In contrast, with $3 \mathrm{~mm}$ HEPES, the $Q_{\mathrm{Ca}}$ ratio was $>1$ (2 msec: $1.22 \pm 0.05 ; 5$ msec: $1.39 \pm 0.08 ; 10$ msec: $1.30 \pm 0.06 ; n=$

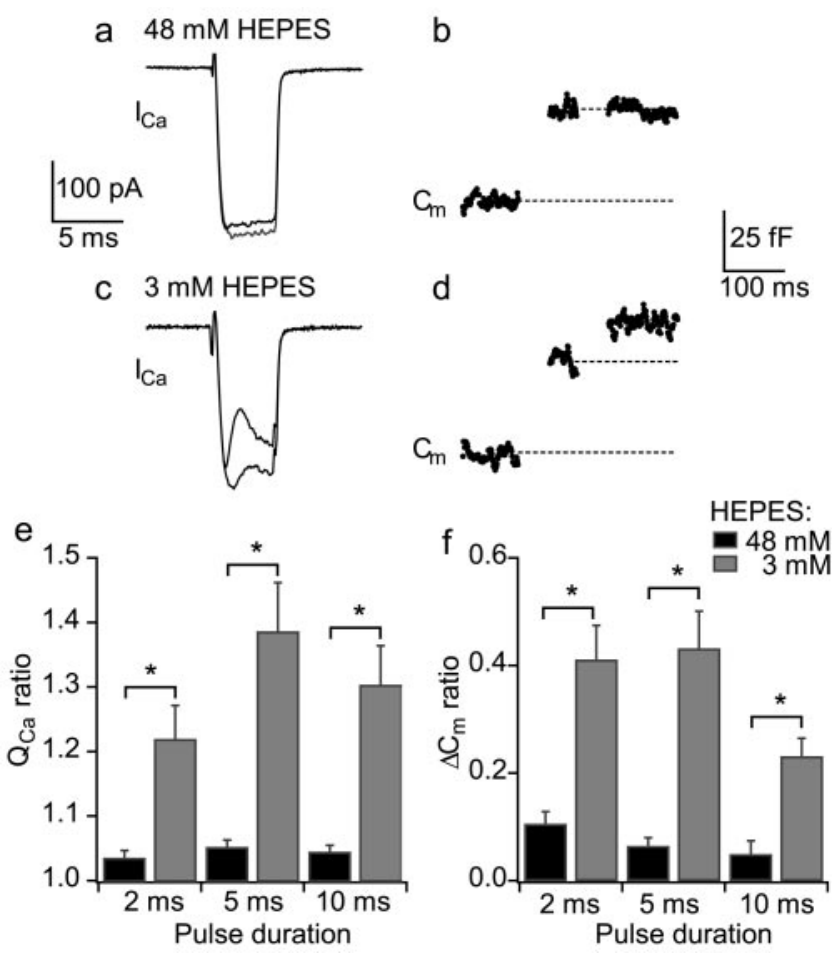

Figure 7. Modulation of paired-pulse depression of exocytosis by pH buffer. $a, I_{\mathrm{Ca}_{\mathrm{a}}}$ evoked by a pair of $5 \mathrm{msec}$ depolarizations (100 msec interval) in the presence of $48 \mathrm{~mm}$ extracellular HEPES, first and second pulse superimposed. $b, \Delta c_{\mathrm{m}}$ evoked by the depolarizations in $a$. No exocytosis was observed after the second pulse. $c, I_{\mathrm{Ca}_{\mathrm{a}}}$ evoked by the same stimulus protocol in a different terminal in the presence of $3 \mathrm{~mm}$ extracellular HEPES. $d, \Delta C_{\mathrm{m}}$ evoked by the depolarizations in c. The second pulse induced exocytosis. $e$, The average $Q_{C a}$ ratios (second pulse/first pulse) for paired depolarizations of 2,5 , and $10 \mathrm{msec}$ duration in the presence of $3 \mathrm{~mm}(n=8)$ and $48 \mathrm{~mm}(n=8)$ extracellular HEPES. The $Q_{\mathrm{Ca}}$ ratios were significantly greater in 3 than $48 \mathrm{~mm}$ extracellular HEPES ( $\left.{ }^{*} p<0.01\right)$. $f$, The average $\Delta C_{m}$ ratios (second pulse/first pulse) for the paired depolarizations in $e$. The $\Delta C_{\mathrm{m}}$ ratios were significantly greater in 3 than $48 \mathrm{~mm}$ HEPES $\left({ }^{*} p<0.01\right)$, indicating a reduction in paired-pulse depression of exocytosis.

8; $p<0.01$ compared with $48 \mathrm{~mm}$ HEPES), attributable to inhibition of first pulse $I_{\mathrm{Ca}}$ (Fig. $7 c, e$ ). This effect was accompanied by a significant increase in the $\Delta C_{\mathrm{m}}$ ratio $(2 \mathrm{msec}: 0.41 \pm 0.07 ; 5$ msec: $0.43 \pm 0.07 ; 10$ msec: $0.23 \pm 0.03 ; n=8$; $p<0.01$ compared with $48 \mathrm{~mm}$ HEPES), indicating a reduction in the amount of paired-pulse depression of exocytosis (Fig. $7 d, f$ ). The suppression of $\mathrm{Ca}^{2+}$ influx that follows exocytosis in the presence of low extracellular $\mathrm{pH}$ buffer therefore enables subsequent, identical depolarizations to evoke greater $\mathrm{Ca}^{2+}$ influx and further release from the terminal.

\section{Paired-pulse depression with physiological $\mathrm{pH}$ buffer}

To investigate the degree of paired-pulse depression of release under more physiological $\mathrm{pH}$ buffering conditions, experiments were performed with HEPES-free, bicarbonate-buffered extracellular solution (24 mM $\left.\mathrm{NaHCO}_{3}, 95 \% \mathrm{O}_{2} / 5 \% \mathrm{CO}_{2}, \mathrm{pH} 7.5\right)$. The average amplitude of second pulse $I_{\mathrm{Ca}}$ under these conditions $(184 \pm 28 \mathrm{pA} ; n=6)$ was not significantly different from that with 3 or $48 \mathrm{~mm}$ HEPES, indicating that the $\mathrm{pH}$ buffering conditions do not directly affect $\mathrm{Ca}^{2+}$ currents in bipolar cell terminals. The average $\Delta C_{\mathrm{m}}$ values evoked by 2 and $25 \mathrm{msec}$ depolarizations were $22 \pm 3 \mathrm{fF}(n=7)$ and $53 \pm 10 \mathrm{fF}(n=6)$, respectively, not significantly different from the values in 3 or 48 mM extracellular HEPES. A relatively large amount of inhibition of first pulse $I_{\mathrm{Ca}}$ was observed in the presence of bicarbonate buffer. For example, pairs of $25 \mathrm{msec}$ depolarizations gave a 
a Bicarbonate
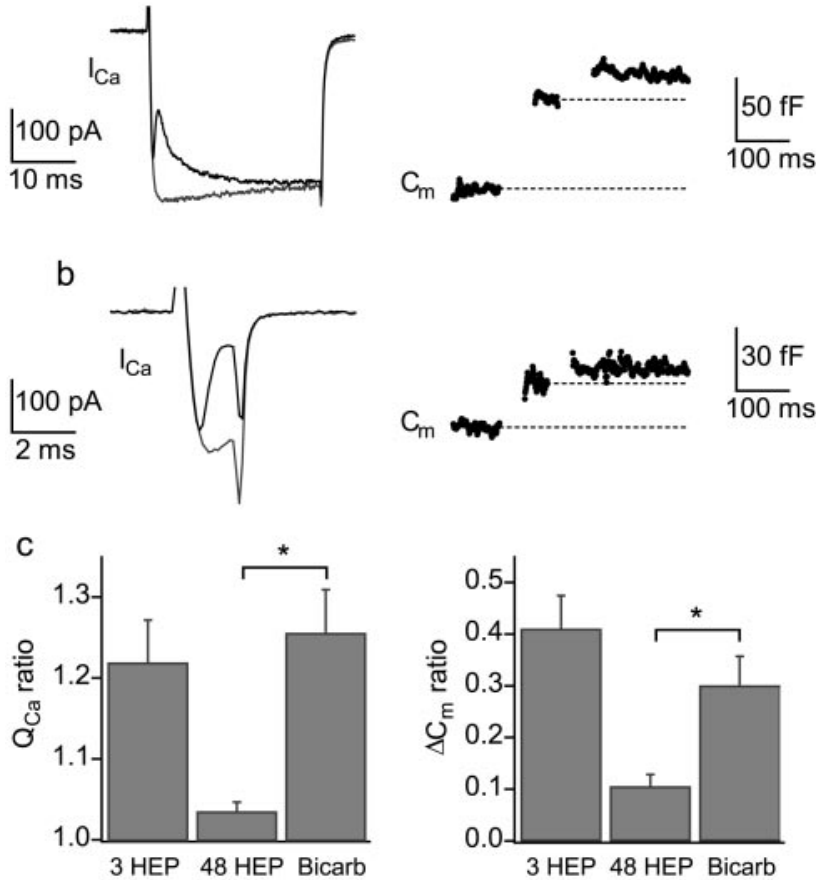

Figure 8. $I_{\text {inhibition }}$ and paired-pulse depression in physiological pH buffer. $a, I_{C_{\mathrm{a}}}$ and $\Delta C_{\mathrm{m}}$ evoked by a pair of $25 \mathrm{msec}$ depolarizations to $-10 \mathrm{mV}$ (100 msec interval) in the presence of HEPES-free, bicarbonate-buffered extracellular solution. Inhibition of first pulse $I_{C_{\mathrm{Ca}}}$ was prominent. $b, I_{C a}$ and $\Delta C_{m}$ evoked by a pair of $2 \mathrm{msec}$ depolarizations in the presence of bicarbonatebuffered extracellular solution. Exocytosis was evoked by the second pulse. c, Average $Q_{C_{a}}$ and $\Delta C_{\mathrm{m}}$ ratios for paired $2 \mathrm{msec}$ depolarizations in the presence of bicarbonate buffer $(n=7)$, plotted for comparison with the values in 3 and $48 \mathrm{~mm}$ extracellular HEPES (from Fig. 8). Both the $Q_{C_{a}}$ and $\Delta C_{m}$ ratios were significantly greater in bicarbonate buffer than $48 \mathrm{~mm} H E P E S$ but not significantly different from $3 \mathrm{~mm}$ HEPES $\left({ }^{*} p<0.05\right)$.

$Q_{\text {inhibition }}$ of $662 \pm 128 \mathrm{pC}(n=6)$ (Fig. $\left.8 a\right)$, close to the value in $3 \mathrm{~mm}$ HEPES. The $Q_{\mathrm{Ca}}$ ratio for pairs of $2 \mathrm{msec}$ depolarizations was $1.26 \pm 0.05$ and the $\Delta C_{\mathrm{m}}$ ratio was $0.30 \pm 0.06(n=7)$ (Fig. $8 b, c)$. This $\Delta C_{\mathrm{m}}$ ratio in bicarbonate buffer is significantly larger than that measured in 12 mM HEPES $(0.10 \pm 0.03 ; n=7 ; p<$ 0.05 ) or $48 \mathrm{~mm}$ HEPES but not significantly different from $3 \mathrm{~mm}$ HEPES, suggesting that 3 mM HEPES more closely mimics physiological $\mathrm{pH}$ buffering in the synaptic cleft.

\section{pH buffering modulates exocytosis evoked by single depolarizations}

The amount of exocytosis evoked by the first of a pair of depolarizations was found to be not significantly affected by $\mathrm{pH}$ buffering when compared between different sets of terminals. To eliminate interterminal variability, exocytosis was measured in the same terminal under different $\mathrm{pH}$ buffering conditions. Rapid exchange of extracellular solution was required because of rundown of exocytosis during recordings (Fig. 3). A pair of $5 \mathrm{msec}$ depolarizations was first delivered in the presence of $24 \mathrm{~mm}$ bicarbonate-buffered extracellular solution and then delivered again, $30 \mathrm{sec}$ later, in the presence of $48 \mathrm{~mm}$ HEPES. As shown in Figure $9 a$, a large amount of inhibition of first pulse $I_{\mathrm{Ca}}$ was observed in the presence of bicarbonate buffer, but, as expected, the inhibition was greatly reduced after perfusion of $48 \mathrm{~mm}$ HEPES $\left(Q_{\mathrm{Ca}}=0.54 \mathrm{pC}\right.$ in bicarbonate, $1.13 \mathrm{pC}$ in $48 \mathrm{~mm}$ HEPES). In addition, $\Delta C_{\mathrm{m}}$ evoked by the first pulse was larger in the presence of $48 \mathrm{mM}$ HEPES ( $52 \mathrm{fF}$ in bicarbonate, $69 \mathrm{fF}$ in 48 mM HEPES) (Fig. 9b), indicating that released vesicular protons
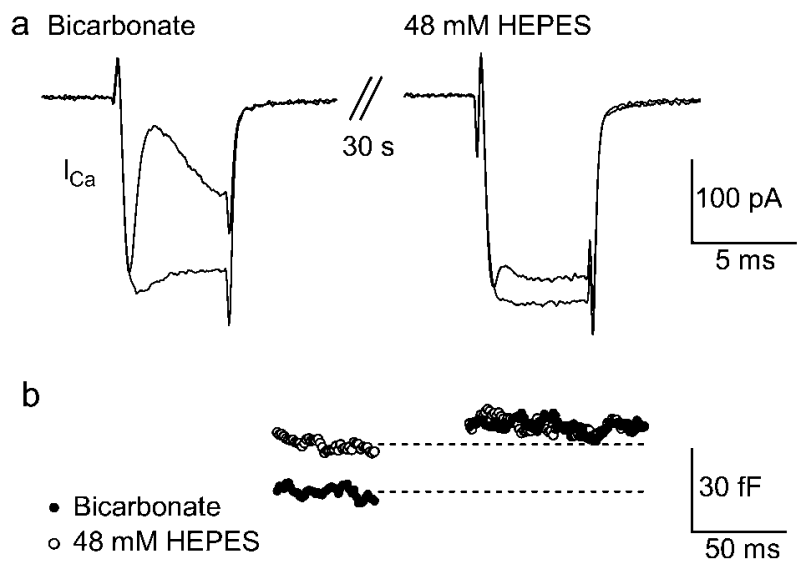

$\mathrm{C}_{\mathrm{m}}$

Figure 9. Modulation of exocytosis evoked by single depolarizations by pH buffer. $a, I_{c a}$ evoked by a pair of $5 \mathrm{msec}$ depolarizations to $-10 \mathrm{mV}$ ( $100 \mathrm{msec}$ interval) in the presence of 24 $\mathrm{mm}$ bicarbonate-buffered extracellular solution (left). $I_{\mathrm{Ca}}$ evoked by the same stimulation protocol in the same terminal after perfusion of extracellular solution containing $48 \mathrm{~mm}$ HEPES (right). Inhibition of first pulse $I_{C_{a}}$ was greatly reduced by $48 \mathrm{~mm}$ HEPES. $b, \Delta C_{m}$ evoked by the paired depolarizations in $a$ (solid symbols represent bicarbonate; open symbols represent 48 $\mathrm{mm}$ HEPES). First pulse $\Delta C_{\mathrm{m}}$ was potentiated after perfusion of $48 \mathrm{~mm} \mathrm{HEPES}$, indicating that ${ }_{\mathrm{Ca}}$ inhibition can reduce exocytosis during single depolarizations. Rapid exchange of bath solution enabled rundown of $\Delta C_{\mathrm{m}}$ to be overcome. The total $\Delta C_{\mathrm{m}}$ to the pair of depolarizations was very similar in both $\mathrm{pH}$ buffering conditions. The large $(\sim 85 \%)$ peak inhibition of $I_{\mathrm{Ca}}(a)$ indicates that the $\mathrm{pH}$ in the synaptic cleft transiently decreased from 7.5 to 6.5 in this example.

can inhibit further exocytosis during single depolarizations. Consistent with the demonstrated effects of $\mathrm{pH}$ buffering on pairedpulse depression, the second depolarization evoked less exocytosis in $48 \mathrm{~mm}$ HEPES than bicarbonate buffer. Consequently, the total amount of exocytosis was very similar under both buffering conditions. A similar increase in $\Delta C_{\mathrm{m}}$ evoked by single $5 \mathrm{msec}$ depolarizations after switching from bicarbonate to $48 \mathrm{~mm}$ HEPES buffered solutions was observed in five additional terminals. $\Delta C_{\mathrm{m}}$ was on average $42 \pm 11 \mathrm{fF}$ in bicarbonate buffer and $81 \pm 21 \mathrm{fF}$ in $48 \mathrm{~mm} \operatorname{HEPES}(p<0.05)$.

\section{Synaptic cleft acidification after exocytosis}

The decay of $I_{\text {inhibition }}$ in the presence of bicarbonate buffer, obtained from a double-exponential fit of the difference current as in Figure 4, was similar to that in $12 \mathrm{~mm}$ HEPES. Mean fast and slow time constants were $905 \mu \mathrm{sec}$ and $7.4 \mathrm{msec}$, respectively ( $n=5 ; 731 \mu \mathrm{sec}$ and $7.6 \mathrm{msec}$ for $12 \mathrm{~mm}$ HEPES). The peak inhibition of $I_{\mathrm{Ca}}$ during a $25 \mathrm{msec}$ depolarization in the presence of bicarbonate buffer was $61 \pm 5 \%(n=11)$. From the results in Figure $6 b$ (dashed line), this would result from a transient acidification in the vicinity of the $\mathrm{Ca}^{2+}$ channels from $\mathrm{pH} 7.5$ to $~ 6.9$. The peak inhibition occurred $2.1 \pm 0.2 \mathrm{msec}$ after the start of the depolarization. Approximately $75 \%$ of the exocytosis during a 25 msec depolarization occurs within the first $2 \mathrm{msec}$ (Fig. $4 b$ ), which equates to $\Delta C_{\mathrm{m}}$ of $40 \mathrm{fF}$ for these recordings. Assuming a vesicle capacitance of $26 \mathrm{aF}$ (von Gersdorff et al., 1996), this corresponds to the release of $\sim 1550$ vesicles, or $\sim 30$ vesicles per ribbon-type active zone with 55 ribbons per terminal (von Gersdorff et al., 1996). If each active zone and postsynaptic target function as an independent "synaptic cleft," the release of $\sim 30$ vesicles causes extracellular acidification of $0.6 \mathrm{pH}$ units under physiological buffering conditions. This is sufficient to cause significant inhibition of further $\mathrm{Ca}^{2+}$ influx and to modulate exo- 
cytosis from the terminal. The speed of the modulation implies that $\mathrm{Ca}^{2+}$ channels must be located within nanometers of vesicle fusion sites, which agrees with recent evidence that hot spots of $\mathrm{Ca}^{2+}$ influx coincide with the location of synaptic ribbons (Morgans, 2001; Zenisek et al., 2003).

\section{Discussion}

This study demonstrates that exocytosis is modulated by released vesicular protons in retinal bipolar cell terminals. The modulation occurs via an inhibition of presynaptic $\mathrm{Ca}^{2+}$ currents, as described previously by DeVries (2001) in photoreceptor terminals. We have shown that in bipolar cell terminals the degree of $\mathrm{Ca}^{2+}$ channel inhibition correlates with the amount of exocytosis, measured as an increase in membrane capacitance, and the inhibition is greatly potentiated by low concentrations of extracellular $\mathrm{pH}$ buffer, consistent with inhibition of $\mathrm{Ca}^{2+}$ channels by released vesicular protons. Furthermore, the $\mathrm{pH}$ buffer concentration significantly affects the amount of paired-pulse depression of exocytosis in bipolar cell terminals. For example, depression was reduced from $94 \%$ in high $\mathrm{pH}$ buffer to $57 \%$ in low $\mathrm{pH}$ buffer for $5 \mathrm{msec}$ depolarizations.

$\mathrm{Ca}^{2+}$ current inhibition by released protons was found to reduce exocytosis evoked by single depolarizations when two buffering conditions were compared in the same terminal; however, the effect was small relative to the inhibition of $I_{\mathrm{Ca}}$ and was not significant between groups of terminals recorded in either high or low concentrations of HEPES. This is likely to be attributable to the rapidly decreasing rate of release during sustained depolarizations (Fig. 4) (Mennerick and Matthews, 1996). Thus, a large amount of release occurs during the first millisecond, further $\mathrm{Ca}^{2+}$ influx is inhibited, but this modulates a much lower release rate and so has little effect on the total $\Delta C_{\mathrm{m}}$. The small effect of $\mathrm{pH}$ buffer on exocytosis evoked by single depolarizations is similar to that reported by DeVries (2001), who observed only a slight increase in postsynaptic responses in two of five recordings in the presence of high $\mathrm{pH}$ buffer. Moreover, this increase may have been caused by actions of protons on either presynaptic or postsynaptic targets. By using $\Delta C_{\mathrm{m}}$ rather than postsynaptic responses to monitor exocytosis, we are able to exclude inhibitory actions of protons on glutamate receptors (Tang et al., 1990; Ihle and Patneau, 2000) as a mechanism for the observed effects.

In bipolar cell terminals, examination of paired-pulse depression revealed significant effects of released vesicular protons on exocytosis. In low extracellular $\mathrm{pH}$ buffer, $\mathrm{Ca}^{2+}$ influx during the first pulse is inhibited by released protons, but the second pulse $\mathrm{Ca}^{2+}$ current is less inhibited because of vesicle depletion. Consequently there is greater $\mathrm{Ca}^{2+}$ influx during the second than the first depolarization, which overcomes paired-pulse depression and evokes further release. Hence $\mathrm{Ca}^{2+}$ current inhibition by released vesicular protons has the net effect of reducing depression of exocytosis.

The results in bicarbonate buffer indicate the extent to which this mechanism occurs under physiological conditions. $\mathrm{Ca}^{2+}$ current inhibition by vesicular protons was prominent with 24 $\mathrm{mm}$ bicarbonate, and the degree of paired-pulse depression of release was closer to that measured in $3 \mathrm{~mm}$ than 12 or $48 \mathrm{~mm}$ HEPES. The apparently low buffering power of bicarbonate $\left(\mathrm{pK}_{\mathrm{a}}\right.$ 6.1) compared with HEPES ( $\mathrm{pK}_{\mathrm{a}} 7.5$ ) may be attributable to exclusion of the enzyme carbonic anhydrase from the synaptic cleft and the resulting reduction in the effective $\mathrm{pK}_{\mathrm{a}}$ of bicarbonate (DeVries, 2001). To obtain an estimate of the change in synaptic cleft $\mathrm{pH}$ after exocytosis with bicarbonate buffer, we first measured the sensitivity of bipolar cell $\mathrm{Ca}^{2+}$ currents to extracellular solutions of varying $\mathrm{pH}$ in dissociated terminals. Acidification caused a decrease in conductance and positive shift in voltagedependent activation, with a sensitivity very similar to that reported in photoreceptors (Barnes and Bui, 1991) and smooth muscle cells (Klockner and Isenberg, 1994). From the $\mathrm{Ca}^{2+}$ current inhibition and $\Delta C_{\mathrm{m}}$ observed after exocytosis in physiological $\mathrm{pH}$ buffer, we estimate that synaptic cleft acidification of $\sim 0.6 \mathrm{pH}$ units results from the rapid release of $\sim 30$ vesicles at each of 55 active zones in a terminal. This represents the $\mathrm{pH}$ change seen by the $\mathrm{Ca}^{2+}$ channels, which are probably located very close to sites of exocytosis (Raviola and Raviola, 1982). DeVries (2001) compared the voltage shift in photoreceptor $\mathrm{Ca}^{2+}$ current activation after exocytosis with the shift evoked by changing extracellular $\mathrm{pH}$ to estimate a synaptic cleft acidification of $0.2 \mathrm{pH}$ units. The higher value obtained in this study is likely to result from various factors, including stronger depolarization, weaker intracellular $\mathrm{Ca}^{2+}$ buffering, and differences in synaptic function and geometry between the two cell types.

The rapid rise and fast decay component of $\mathrm{Ca}^{2+}$ current inhibition in bipolar cell terminals were observed to closely reflect the rate of exocytosis with a delay of $\sim 1 \mathrm{msec}$, consistent with a rapid effect of released protons on $\mathrm{Ca}^{2+}$ channels (Prod'hom et al., 1987). The additional slower component to the decay of the inhibition $(\tau \sim 7.5 \mathrm{msec})$ is likely to represent the rate of clearance of protons from the synaptic cleft by buffering and diffusion. This rate was similar in the presence of 12 mM HEPES and $24 \mathrm{~mm}$ bicarbonate buffers. By contrast, the decay of the equivalent difference current in photoreceptors was well fit by a single exponential ( $\tau=1.8 \mathrm{msec}$ ) (DeVries, 2001).

Bipolar cells generally respond to light with graded changes in membrane potential around the $\mathrm{Ca}^{2+}$ channel activation voltage (Saito et al., 1979; Ashmore and Falk, 1980). Depolarization in the physiological range to approximately $-30 \mathrm{mV}$ is likely to release approximately half as many vesicles as depolarization to $-10 \mathrm{mV}$ (Burrone and Lagnado, 2000) and result in synaptic cleft acidification from $\mathrm{pH} 7.5$ to $\sim 7.2$. We have observed that acidification to $\mathrm{pH} 7.0$ at $-30 \mathrm{mV}$ causes a 3.4-fold decrease in $\mathrm{Ca}^{2+}$ channel conductance and from this estimate an approximate twofold decrease at $\mathrm{pH}$ 7.2. Bipolar cell terminal $\mathrm{Ca}^{2+}$ influx is therefore likely to be halved by proton-mediated feedback during physiological depolarizations. The effect of this is likely to depend on the bipolar cell response kinetics. ON-bipolar cells exhibit either a sustained $\left(t_{\text {decay }} \sim 4.0 \mathrm{sec}\right)$ or more transient $\left(t_{\text {decay }} \sim 0.4\right.$ $s e c$ ) depolarization in response to step illumination (Awatramani and Slaughter, 2000). During sustained depolarization, continuous exocytosis will occur at a low rate, resulting in a steady proton concentration in the synaptic cleft. $\mathrm{Ca}^{2+}$ influx will be tonically reduced and a state of equilibrium is likely to be reached between exocytosis and inhibition. This will reduce depletion of the releasable pool of synaptic vesicles during the depolarization and may enable the bipolar cell to respond more strongly to subsequent increases in stimulation intensity. In transient bipolar cells, the observed proton-mediated feedback effect of reducing paired-pulse depression may be more important. This mechanism would enable maintained responsiveness to high-frequency illumination and may aid in the perception of movement.

Other systems exist at bipolar cell synapses that exert more indirect negative feedback. For example, reciprocal amacrine cell synapses counteract bipolar cell depolarization via activation of ionotropic GABA receptors in the terminal (Tachibana and Kaneko, 1987; Lukasiewicz and Werblin, 1994; Hartveit, 1999). Bipolar cell terminals also contain glutamate transporters with a large associated anion current (Palmer et al., 2003), which will 
tend to hyperpolarize the terminal after exocytosis, and metabotropic glutamate receptors that inhibit transmitter release (Awatramani and Slaughter, 2001), as well as $\mathrm{Ca}^{2+}$-activated $\mathrm{K}^{+}$ (Sakaba et al., 1997) and $\mathrm{Cl}^{-}$currents (Okada et al., 1995; Protti et al., 2000). It remains to be determined how inhibition of $\mathrm{Ca}^{2+}$ currents by vesicular protons interacts with these systems and with vesicle depletion to determine bipolar cell output.

The inhibition of $\mathrm{Ca}^{2+}$ channels by released protons may also function to reduce $\mathrm{Ca}^{2+}$ influx during periods when exocytosis is depressed by other mechanisms, thereby reducing the metabolic demands of $\mathrm{Ca}^{2+}$ clearance from the terminal. $\mathrm{Ca}^{2+}$ clearance is mediated predominantly by a cell membrane $\mathrm{Ca}^{2+}$ ATPase and a $\mathrm{Na}^{+}-\mathrm{Ca}^{2+}$ exchanger (Kobayashi and Tachibana, 1995; Zenisek and Matthews, 2000). The activity of cell membrane $\mathrm{Ca}^{2+}$ pumps is reported to be $\mathrm{pH}$ dependent (inhibited by extracellular alkalization) (Dipolo and Beaugé, 1982), so acidification of the synaptic cleft after exocytosis may act to speed the decay of the intracellular $\mathrm{Ca}^{2+}$ transient (Kobayashi and Tachibana, 1995).

Protons released from exocytosed vesicles are likely to exert effects in the synaptic cleft in addition to their actions on $\mathrm{Ca}^{2+}$ channels and pumps. For example, AMPA and NMDA glutamate receptors, which are present in postsynaptic amacrine and ganglion cells, are modulated by extracellular protons (Tang et al., 1990; Ihle and Patneau, 2000), and glutamate transporterassociated anion currents in bipolar cell terminals are potentiated in low extracellular pH buffer (Palmer et al., 2003). Vesicular protons may therefore be a significant modulator of synaptic function. It is at present unknown whether exocytosed protons cause $\mathrm{Ca}^{2+}$ current inhibition or other effects at conventional (i.e., non-ribbon) central synapses. At such synapses, exocytosis is evoked by rapidly deactivating $\mathrm{Ca}^{2+}$ currents in response to invading action potentials and normally involves the release of only one or a few vesicles at each active zone (Meyer et al., 2001). The resulting change in extracellular $\mathrm{pH}$ is therefore likely to be much smaller than at ribbon synapses.

In conclusion, the results of this study demonstrate a novel form of synaptic modulation that involves exocytosed vesicular protons acting via inhibition of presynaptic $\mathrm{Ca}^{2+}$ influx to reduce short-term synaptic depression. This mechanism may be a characteristic feature of ribbon-type synapses. The possibility that released vesicular protons act via multiple targets to modulate synaptic function throughout the nervous system is ripe for exploration (Bianchi and Driscoll, 2002).

\section{References}

Akopian A (2003) Differential modulation of light-evoked On- and OffEPSCs by paired-pulse stimulation in salamander retinal ganglion cells. Brain Res 967:235-246.

Ashmore JF, Falk G (1980) Responses of rod bipolar cells in the darkadapted retina of the dogfish, Scyliorhinus canicula. J Physiol (Lond) 300:115-150.

Awatramani GB, Slaughter MM (2000) Origin of transient and sustained responses in ganglion cells of the retina. J Neurosci 20:7087-7095.

Awatramani GB, Slaughter MM (2001) Intensity-dependent, rapid activation of presynaptic metabotropic glutamate receptors at a central synapse. J Neurosci 21:741-749.

Barnes S, Bui Q (1991) Modulation of calcium-activated chloride current via $\mathrm{pH}$-induced changes of calcium channel properties in cone photoreceptors. J Neurosci 11:4015-4023.

Barnes S, Merchant V, Mahmud F (1993) Modulation of transmission gain by protons at the photoreceptor output synapse. Proc Natl Acad Sci USA 90:10081-10085.

Bellingham MC, Walmsley B (1999) A novel presynaptic inhibitory mechanism underlies paired pulse depression at a fast central synapse. Neuron 23:159-170.
Bianchi L, Driscoll M (2002) Protons at the gate: DEG/EnaC ion channels help us feel and remember. Neuron 34:337-340.

Burrone J, Lagnado L (2000) Synaptic depression and the kinetics of exocytosis in retinal bipolar cells. J Neurosci 20:568-578.

DeVries SH (2001) Exocytosed protons feedback to suppress the $\mathrm{Ca}^{2+}$ current in mammalian cone photoreceptors. Neuron 32:1107-1117.

Dipolo R, Beaugé L (1982) The effect of $\mathrm{pH}$ on $\mathrm{Ca}^{2+}$ extrusion mechanisms in dialyzed squid axons. Biochim Biophys Acta 688:237-245.

Gillis KD (2000) Admittance-based measurement of membrane capacitance using the EPC-9 patch-clamp amplifier. Eur J Physiol 439:655-664.

Gomis A, Burrone J, Lagnado L (1999) Two actions of calcium regulate the supply of releasable vesicles at the ribbon synapse of retinal bipolar cells. J Neurosci 19:6309-6317.

Hartveit E (1999) Reciprocal synaptic interactions between rod bipolar cells and amacrine cells in the rat retina. J Neurophysiol 81:2923-2936.

Heidelberger R, Matthews G (1992) Calcium influx and calcium current in single synaptic terminals of goldfish retinal bipolar neurons. J Physiol (Lond) 447:235-256.

Hess P, Lansman JB, Tsien RW (1986) Calcium channel selectivity for divalent and monovalent cations. Voltage and concentration dependence of single channel current in ventricular heart cells. J Gen Physiol 88:293-319.

Hsu S-F, Augustine GJ, Jackson MB (1996) Adaptation of $\mathrm{Ca}^{2+}$-triggered exocytosis in presynaptic terminals. Neuron 17:501-512.

Ihle EC, Patneau DK (2000) Modulation of $\alpha$-amino-3-hydroxy-5-methyl4-isoxazolepropionic acid receptor desensitization by extracellular protons. Mol Pharmacol 58:1204-1212.

Iijima T, Ciani S, Hagiwara S (1986) Effects of the external pH on Ca channels: experimental studies and theoretical considerations using a two-site, two-ion model. Proc Natl Acad Sci USA 83:654-658.

Ishida AT, Stell WK, Lightfoot DO (1980) Rod and cone inputs to bipolar cells in goldfish retina. J Comp Neurol 191:315-335.

Klockner U, Isenberg G (1994) Calcium channel current of vascular smooth muscle cells: extracellular protons modulate gating and single channel conductance. J Gen Physiol 103:665-678.

Kobayashi K, Tachibana M (1995) $\mathrm{Ca}^{2+}$ regulation in the presynaptic terminals of goldfish retinal bipolar cells. J Physiol (Lond) 483:79-94.

Korn H, Faber DS, Burnod Y, Triller A (1984) Regulation of efficacy at central synapses. J Neurosci 4:125-130.

Krishtal OA, Osipchuk YV, Shelest TN, Smirnoff SV (1987) Rapid extracellular $\mathrm{pH}$ transients related to synaptic transmission in rat hippocampal slices. Brain Res 436:352-356.

Liu Y, Edwards RH (1997) The role of vesicular transport proteins in synaptic transmission and neural degeneration. Annu Rev Neurosci 20:125-156.

Lukasiewicz PD, Werblin FS (1994) A novel GABA receptor modulates synaptic transmission from bipolar to ganglion and amacrine cells in the tiger salamander retina. J Neurosci 14:1213-1223.

Mennerick S, Matthews G (1996) Ultrafast exocytosis elicited by calcium current in synaptic terminals of retinal bipolar neurons. Neuron 17:1241-1249.

Meyer AC, Neher E, Schneggenburger R (2001) Estimation of quantal size and number of functional active zones at the calyx of Held synapse by nonstationary EPSC variance analysis. J Neurosci 21:7889-7900.

Miesenböck G, De Angelis DA, Rothman JE (1998) Visualizing secretion and synaptic transmission with $\mathrm{pH}$-sensitive green fluorescent proteins. Nature 394:192-195.

Morgans CW (2001) Localization of the $\alpha 1 \mathrm{~F}$ calcium channel subunit in the rat retina. Invest Ophthalmol Vis Sci 42:2414-2418.

Moser T, Beutner D (2000) Kinetics of exocytosis and endocytosis at the cochlear inner hair cell afferent synapse of the mouse. Proc Natl Acad Sci USA 97:883-888.

Okada T, Horiguchi H, Tachibana M (1995) $\mathrm{Ca}^{2+}$-dependent $\mathrm{Cl}^{-}$current at the presynaptic terminals of goldfish retinal bipolar cells. Neurosci Res 23:297-303.

Palmer MJ, Taschenberger H, Hull C, Tremere L, von Gersdorff H (2003) Synaptic activation of presynaptic glutamate transporters in nerve terminals. J Neurosci 23:4831-4841.

Parsons T, Sterling P (2003) Synaptic ribbon: conveyor belt or safety belt? Neuron 37:379-382.

Prod'hom B, Pietrobon D, Hess P (1987) Direct measurement of proton transfer rates to a group controlling the dihydropyridine-sensitive $\mathrm{Ca}^{2+}$ channel. Nature 329:243-246. 
Protti DA, Flores-Herr N, von Gersdorff H (2000) Light evokes $\mathrm{Ca}^{2+}$ spikes in the axon terminal of a retinal bipolar cell. Neuron 25:215-227.

Raviola E, Raviola G (1982) Structure of the synaptic membranes in the inner plexiform layer of the retina: a freeze-fracture study in monkeys and rabbits. J Comp Neurol 209:233-248.

Saito T, Kujiraoka T (1982) Physiological and morphological identification of two types of on-center bipolar cells in the carp retina. J Comp Neurol 205:161-170.

Saito T, Kondo H, Toyoda J-I (1979) Ionic mechanisms of two types of on-center bipolar cells in the carp retina. J Gen Physiol 73:73-90.

Sakaba T, Ishikane H, Tachibana M (1997) $\mathrm{Ca}^{2+}$-activated $\mathrm{K}^{+}$current at presynaptic terminals of goldfish retinal bipolar cells. Neuroscience Res 27:219-228.

Sherry DM, Yazulla S (1993) Goldfish bipolar cells and axon terminal patterns: a Golgi study. J Comp Neurol 329:188-200.

Tachibana M, Kaneko A (1987) $\gamma$-Aminobutyric acid exerts a local inhibitory action on the axon terminal of bipolar cells: evidence for negative feedback from amacrine cells. Proc Natl Acad Sci USA 84:3501-3505.

Tachibana M, Okada T, Arimura T, Kobayashi K, Piccolino M (1993) Dihydropyridine-sensitive calcium current mediates neurotransmitter release from bipolar cells of the goldfish retina. J Neurosci 13:2898-2909.
Tang C, Dichter M, Morad M (1990) Modulation of the N-methyl-Daspartate channel by extracellular $\mathrm{H}^{+}$. Proc Natl Acad Sci USA 87:6445-6449.

Taylor WR, Morgans C (1998) Localization and properties of voltage-gated calcium channels in cone photoreceptors of Tupaia belangeri. Vis Neurosci 15:541-552.

Traynelis SF, Chesler M (2001) Proton release as a modulator of presynaptic function. Neuron 32:960-962.

von Gersdorff H, Matthews G (1994) Dynamics of synaptic vesicle fusion and membrane retrieval in synaptic terminals. Nature 367:735-739.

von Gersdorff H, Matthews G (1997) Depletion and replenishment of vesicle pools at a ribbon-type synaptic terminal. J Neurosci 17:1919-1927.

von Gersdorff H, Vardi E, Matthews G, Sterling P (1996) Evidence that vesicles on the synaptic ribbon of retinal bipolar cells can be rapidly released. Neuron 16:1221-1227.

Witkovsky P, Dowling JE (1969) Synaptic relationships in the plexiform layers of carp retina. Z Zellforsch Mikrosk Anat 100:60-82.

Zenisek D, Matthews G (2000) The role of mitochondria in presynaptic calcium handling at a ribbon synapse. Neuron 25:229-237.

Zenisek D, Davila V, Wan L, Almers W (2003) Imaging calcium entry sites and ribbon structures in two presynaptic cells. J Neurosci 23:2538-2548. 